\title{
Soil nematode community changes associated with windfall and wildfire in forest soil at the High Tatras National Park, Slovak Republic
}

\author{
A. ČEREVKOVÁ, M. RENČO \\ Parasitological Institute, Slovak Academy of Sciences, Hlinkova 3, 04001 Košice, Slovak Republic, \\ E-mail:cerev@saske.sk,renco@saske.sk
}

\begin{abstract}
Summary
The paper presents research findings on the influence of windfall and wildfire on nematode communities in Lariceto-Piceetum forest in the High Tatras in Slovakia. Comparison was made of an intact (REF), affected and extracted (EXT), non-extracted (NEX) and burnt (FIR) forest stand. A total of 55 species belonging to 36 genera were found. The EXT locality harboured the majority of the identified species, but the highest abundance of nematodes was observed in the FIR locality. Bacterial feeders were the dominant trophic group in all investigated plots. In the REF bacterial feeders were followed by root-fungal feeders, fungal feeders and omnivores, in the EXT by omnivores and plant parasites, in the FIR by omnivores and root-fungal feeders and in the NEX by fungal feeders and omnivores. The MI and SI were higher in the REF and the EXT compared to those in the FIR and the NEX, the highest $\mathrm{B} / \mathrm{F}$ ratio was observed in the FIR and the highest EI was found in the REF. We can conclude that disturbance of forest vegetation and soil has had a clear and demonstrable impact on nematode communities.
\end{abstract}

Keywords: Soil nematodes; diversity; windfall; wildfire; disturbance of forest soil

\section{Introduction}

In November 2004, a massive windfall caused by a storm destroyed 12500 ha of the forest stands (LaricetoPiceetum) in the High Tatras. In July 2005, a wildfire scorched some 250 ha. Some parts were left unmanaged, but the bulk of the disturbed area (95\%) was extracted. These catastrophic disturbances have resulted in massive changes of vegetation, soil and microclimatic conditions within the windfall area.

Nematodes have characteristics that allow them to be used as biological indicators (Bongers, 1990, De Goede et al., 1993, Wasilewska 1997, Ferris et al., 2001). Changes in the ecosystem are reflected in the abundance of nematodes, diversity, species composition, proportion of different trophic groups and ecological indexes. The structure and composition of nematode fauna in forest soil have been studied in many countries (Armendariz et al., 1996, Sohlenius \& Boström, 2001, Háněl 2003 etc.) and in Slovakia by Š́ly (1983), Lišková et al. (2008) and Lišková (2008). Distinct changes of composition of nematode communities in forest soil in relation to human disturbance have been documented by Romanenko et al. (1997), Bloemers et al. (1997); after clear-cut by Sohlenius (1996, 1997, 2002), Háněl (2004); in burned forest by Fenster et al. (2004); in managed forest by Bjørnlund et al. (2002), Pavao-Zuckerman and Coleman (2007) and others.

In this paper, the composition of the soil nematode fauna, the proportions of trophic groups, together with selected ecological indices were studied to evaluate impact of windfall and wildfire on nematode communities in the disturbed forest stands.

\section{Material and methods}

Investigations were carried out in four research plots (each of $100 \mathrm{ha}$ ) in the north part of the Slovak Republic in the High Tatras.

Characteristics of the study plots:

REF - reference, intact forest is situated in the area of Vyšné Hágy $\left(49^{\circ} 07^{\prime} \mathrm{N}, 20^{\circ} 47^{\prime} \mathrm{E}\right)$. Mature spruce forest was affected neither by a windfall nor by a wildfire. Original plant formation is Lariceto-Piceetum forest with a herbaceous undergrowth mainly represented by the shrub Maianthemum bifolium (L.) F. W. Schmidt, plant and herbs Oxalis acetosella L., Vaccinium myrtillus L., Calamagrostis villosa (Chaix ex Vill.) J. F. Gmel, Avenella flexuosa (L.) Parl. 
Table 1 Characteristic of investigated research plots Fleischer and Koreň (2007); pedochemical characteristic Šimonovičová et al. (2007); $\mathrm{REF}$ - reference, intact forest; EXT - extracted forest; FIR - burnt forest; NEX - non-extracted unmanaged forest

\begin{tabular}{|c|c|c|c|c|}
\hline & REF & EXT & FIR & NEX \\
\hline Altitude research plot (a.s.l) & $1100-1250$ & $1040-1260$ & $1000-1200$ & $1050-1150$ \\
\hline Orientation & SE & $\mathrm{S}$ & SE & SE-S \\
\hline Slope $\%$ & $10-20$ & 10 & $5-10$ & $5-10$ \\
\hline Forest community & Lariceto-Piceetum & Lariceto-Piceetum & Lariceto-Piceetum & Lariceto-Piceetum \\
\hline \multirow[t]{2}{*}{ Tree $\%$ before windfall } & Spruce 70 & Spruce 90 & Spruce 70 & Spruce 70 \\
\hline & Larch 30 & Larch 10 & Larch 30 & $\begin{array}{l}\text { Pine } 20 \\
\text { Larch } 10\end{array}$ \\
\hline Tree age before windfall & 80 & 80 & $120 / 25$ & $125 / 60 / 25$ \\
\hline Soil & Cambisol podzolic & Cambisol podzolic & Cambisol podzolic & Cambisol podzolic \\
\hline $\mathrm{pH}\left(\mathrm{H}_{2} \mathrm{O}\right)$ & 4.16 & 3.85 & 4.06 & 4.33 \\
\hline $\mathrm{C}_{\mathrm{Ox}} \%$ & 2.8 & 2.6 & 4.2 & 5.3 \\
\hline $\mathrm{N}_{\text {tot }} \%$ & 0.2 & 0.3 & 0.44 & 0.4 \\
\hline $\mathrm{C} / \mathrm{N}$ & 14.0 & 8.7 & 9.54 & 13.2 \\
\hline
\end{tabular}

EXT - extracted forest; Danielov dom $\left(49^{\circ} 07^{\prime} \mathrm{N}\right.$, $20^{\circ} 09^{\prime} \mathrm{E}$ ), the locality destroyed by a windfall where fallen trees were cleared out. Dense grass and herbs covered the stand with dominating Calamagrostis villosa (Chaix ex Vill.) J. F. Gmel, Avenella flexuosa (L.) Parl.

FIR - burnt forest; Tatranské Zruby $\left(49^{\circ} 07^{\prime} \mathrm{N}, 20^{\circ} 11^{\prime} \mathrm{E}\right)$ the locality affected by fire, the fallen trees were partly extracted, the area is covered by a layer of ash, sparse vegetation with a dominance of Avenella flexuosa (L.), Calamagrostis villosa (Chaix ex Vill.) J. F. Gmel, Chamerion angustifolium (L.) Holub.

NEX - non-extracted unmanaged forest; Tatranská Lomnica - Jamy $\left(49^{\circ} 09^{\prime} \mathrm{N}, 20^{\circ} 15^{\prime} \mathrm{E}\right)$ fallen trees have been left to natural succession. The undergrowth comparable with those in the intact forest but light-demanding species as Calamagrostis villosa are absent. The composition of plant communities on research plots was investigated by Šimonovičová et al. (2007). More information about reasears plots are given in Table 1

At each of the research plots, five stands $\left(100 \mathrm{~m}^{2}\right)$ were selected for investigating the nematode communities. Sampling was carried out in June and October 2006. A total of 40 soil samples (four research plots, five stands at each plot, sampled twice a year) were collected at a depth of $10 \mathrm{~cm}$. One a bulked sample consisted of five sub-samples collected at each stand in individual sampling dates. Nematodes were isolated from $100 \mathrm{~g}$ of mixed soil samples by the Baermann method (1917), fixed in FAA and studied in permanent glycerine slides. Juveniles were identified to the genus level. Nematode species were allocated to trophic groups according to Yeates et al. (1993). Community indices were calculated as Shannon Index H'spp calculated for species and H'gen calculated for genera (Shannon \& Weaver, 1949); Maturity Index (MI) and Plant Parasite Index (PPI) proposed by Bongers (1990); PPI/MI (Bongers \& Korthals, 1995); B/F (Wasilewska, 1997); Enrichment Index (EI) and Structure Index (SI) according to Ferris et al. (2001) with weightings of nematode taxa as suggested by the authors. The weightings for the taxa not included in the paper were derived from c-p values by Bongers (1990).
All indices, as well as a total abundance of nematodes, H'spp, H'gen, percentage proportion of trophic groups and ecological indexes are calculated as the mean value with standard deviation for all research plots. Statistical calculations were performed by the STATISTICA, ANOVA post-hoc Fisher test and Cluster analysis Ward's method (StatSoft, 2001).

\section{Results}

\section{Taxonomic evaluation}

A total of 55 species from 36 genera, including unidentified juveniles listed as nematode sp. were identified (Table 2). The most of identified species and genera (46 resp. 31) were found in EXT; and the least (38 resp. 28) in the NEX locality. The abundance of nematodes in soil samples varied from 89 to 963 in $100 \mathrm{~g}$ of soil and was significantly higher in the FIR $(606 \pm 208.4)$ compared to other localities. The least abundance of nematodes was observed in the REF locality $(249 \pm 116.1)$ (Table 3$)$.

The majority of identified nematode species belonged to the orders Dorylaimida (16), Tylenchida (11), Araeolaimida and Rhabditida (both 8). Dominant species (Table 2 ) at all four plots were Acrobeloides nanus (10 - $32 \%)$ and Eudorylaimus silvaticus (6 - $10 \%)$. In addition to them, in the REF locality the species included Malenchus exiguus (12\%), Filenchus vulgaris and Tylencholaimus mirabilis (both $9 \%$ ), Plectus parietinus and Aphelenchoides composticola (both $6 \%$ ); in the EXT they included Paratylenchus microdorus (13\%), Teratocephalus terrestris $(7 \%)$ and P. parietinus (6\%); in the FIR Cephalobus persegnis $(8 \%), T$. terrestris $(7 \%), F$. vulgaris and $P$. parietinus (both $6 \%$ ); and in the NEX A. composticola and $C$. persegnis (both $7 \%$ ). Several species occurred only in the REF, i.e. Criconemoides morgensis, Diphtherophora communis, Eudorylaimus iners, Paratylenchus projectus, Tripyla filicaudata and Tylenchorhynchus sp.

Values of Shannon Index for species H'spp varied from 1.10 (NEX) to 2.84 (REF). However, as the different number of nematode species and their abundance were found, 


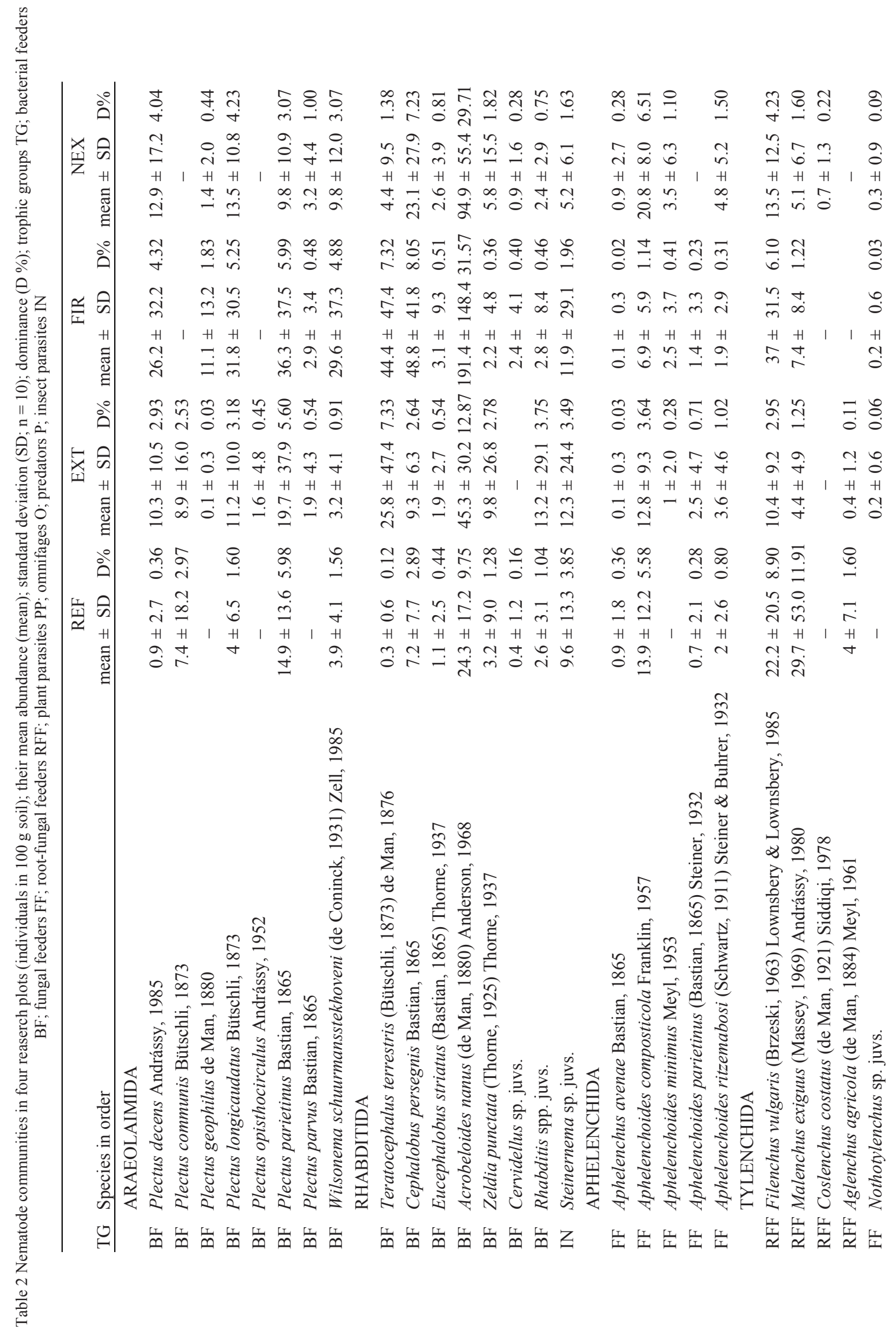




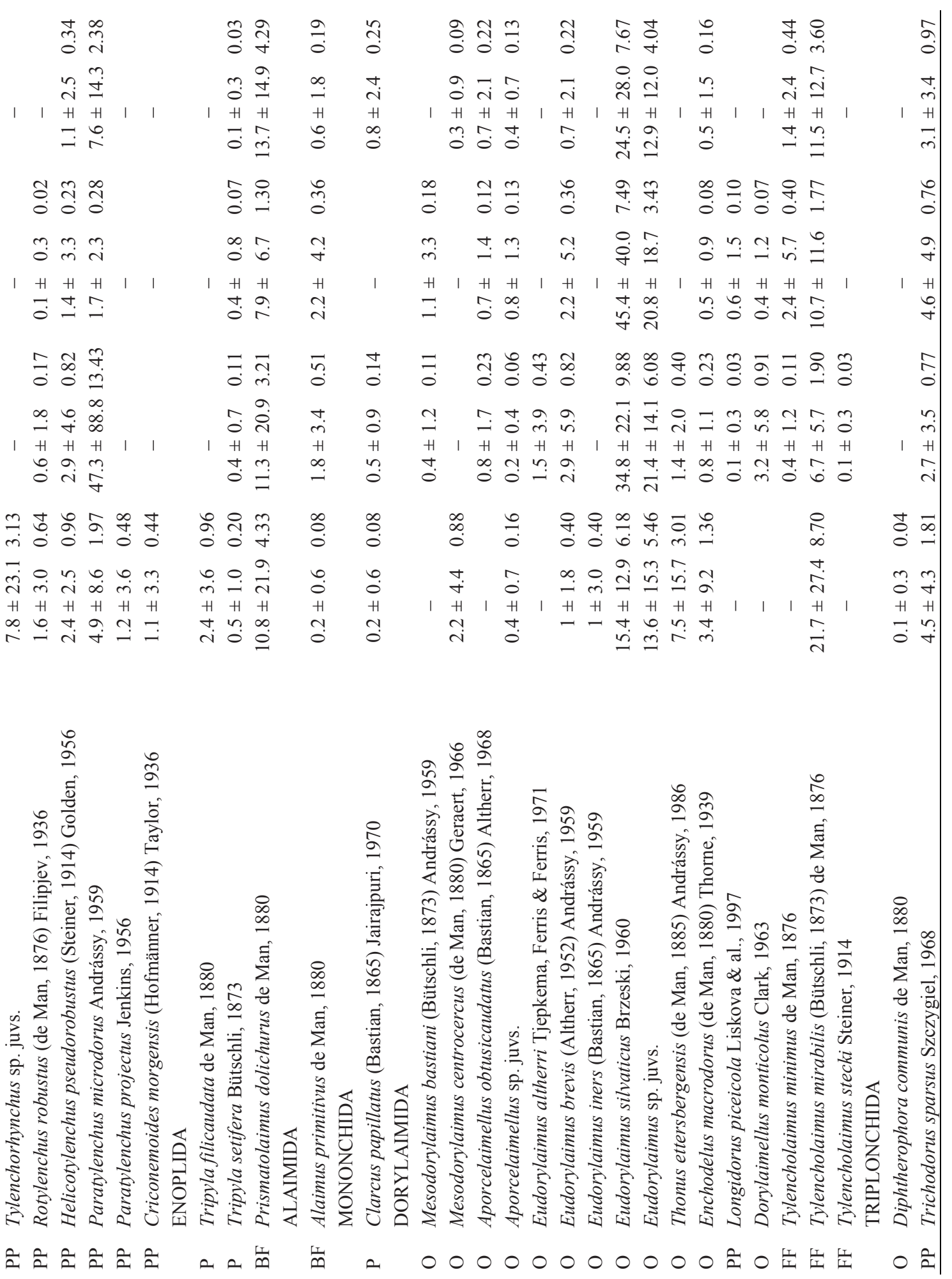


no significant differences in H'spp were observed. Shannon index for genera H'gen varied from 1.02 (EXT) to 2.75 (FIR) with significant differences in the EXT. Cluster analysis performed on species population densities (Fig. 1) showed four clusters. First cluster included only three stands of the REF locality, second cluster combines stands of REF, NEX and EXT, next cluster included three stands of NEX and EXT localities and the latest cluster clearly separated the FIR locality
NEX this species was totally absent.

In the EXT and FIR, bacterial feeders were followed by omnivores with a higher proportion in the EXT (22\%), followed by the FIR (12\%) with a dominance of Eudorylaimus species. Differences between EXT and FIR were also found in plant parasites with higher proportions in EXT (13\%) caused by the dominance of the species Paratylenchus microdorus. The proportion of plant parasites in the FIR was only $1.5 \%$.

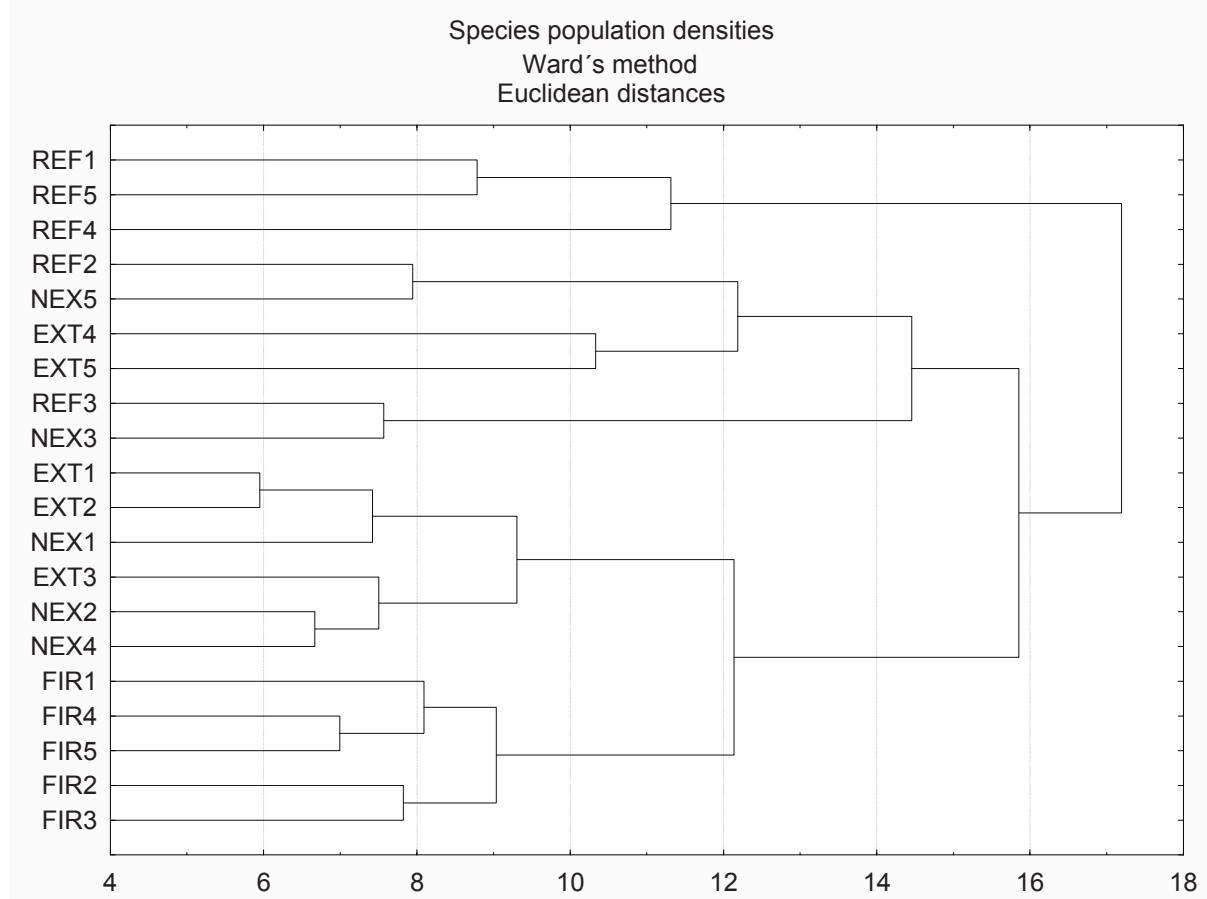

Fig. 1. Cluster analysis of nematode species densities in four forest stands; REF- reference, EXT extracted forest, FIR burn ferest, NEX non-extracted forest. Data $\log (\mathrm{x}+1)$, where $\mathrm{x}=$ species population density in two times

Trophic groups, functional diversity, food web diagnostic The bacterial feeders (Table 3) were the dominant trophic group at all research plots, represented mainly by $A$. nanus, C. persegnis, Plectus spp., Prismatolaimus dolichurus, besides them in the EXT by Rhabditis spp., T. terrestris and Zeldia punctata, in the FIR and NEX also by Wilsonema schuurmansstekhoveni. The proportion of bacterial feeders was significantly higher in the FIR and NEX compared to those in the REF and EXT localities.

In the REF, bacterial feeders were followed by root-fungal feeders, represented mainly by Filenchus vulgaris and Malenchus exiguus. The proportion of the root-fungal feeders was significantly higher in the REF compared to those in the EXT, FIR or NEX localities. Fungal feeders were the following trophic group, represented mainly by Aphelenchoides and Tylencholaimus and a group of omnivores represented mainly by Enchodelus and Eudorylaimus. The predators were the least abundant trophic group in the REF, but their abundance was significantly higher in comparison with those in the EXT, FIR and NEX. A higher proportion of predators in the REF was caused by the species Tripyla filicaudata while in the EXT, FIR and
In the NEX, bacterial feeders were followed by fungal feeders, represented mainly by Aphelenchoides with a significantly higher proportion than those in the FIR. The following trophic group was root-fungal feeders with preponderance of Filenchus vulgaris.

The values of Maturity Index (MI) calculated without plant parasites ranged from 2.02 (NEX) to 3.72 (REF). The MI values were significantly higher in the REF and the EXT localities in comparison to the FIR or the NEX localities, which was caused by a higher abundance of nematodes intolerant to the changes in soil condition (e.g. Enchodelus, Eudorylaimus, Thonus) in the REF and the EXT. Nematodes more tolerant to changes (e.g. Acrobeloides and Plectus) were more abundant in the FIR and EXT localities. The Plant Parasites Index (PPI) values were similar at all investigated plots.

The low proportion of PPI/MI ratio (mean value less then 0.9 ) at the REF and the EXT localities are characteristic for natural ecosystems. The highest PPI/MI ratio was found in the FIR with a significant difference only in the EXT locality.

The $\mathrm{B} / \mathrm{F}$ ratio was the highest at the FIR where bacterial 
Table 3 Communitie indices of soil nematodes mean \pm SD $(n=10)$. Significant differences detected by ANOVA, post-hoc Fisher test among treatments, are indicated by different letters $(* \mathrm{P}<0.05)$

\begin{tabular}{|c|c|c|c|c|c|c|c|c|}
\hline & \multicolumn{2}{|r|}{ REF } & \multicolumn{2}{|r|}{ EXT } & \multicolumn{2}{|r|}{ FIR } & \multicolumn{2}{|r|}{$\mathrm{NEX}$} \\
\hline & mean & $\pm \mathrm{SD}$ & mean & $\pm \mathrm{SD}$ & mean & $\pm \mathrm{SD}$ & mean & $\pm \mathrm{SD}$ \\
\hline Number of species & \multicolumn{2}{|r|}{42} & \multicolumn{2}{|r|}{46} & \multicolumn{2}{|c|}{40} & \multicolumn{2}{|r|}{38} \\
\hline Number of genera & \multicolumn{2}{|r|}{32} & \multicolumn{2}{|r|}{31} & \multicolumn{2}{|r|}{29} & \multicolumn{2}{|r|}{28} \\
\hline Abundance & 249.3 & $\pm 116.14^{\mathrm{a}}$ & 352.1 & $\pm 170.17^{\mathrm{ab}}$ & 606.2 & $\pm 208.42^{\mathrm{c}}$ & 319.4 & $\pm 147.95^{\mathrm{a}}$ \\
\hline H'spp & 2.25 & $\pm 0.33^{\mathrm{a}}$ & 2.25 & $\pm 0.25^{\mathrm{a}}$ & 2.08 & $\pm 0.30^{\mathrm{a}}$ & 2.07 & $\pm 0.50^{\mathrm{a}}$ \\
\hline H'gen & 2.09 & $\pm 0,18^{\mathrm{a}}$ & 1.73 & $\pm 0.43^{b}$ & 2.17 & $\pm 0.28^{\mathrm{a}}$ & 2.10 & $\pm 0.20^{\mathrm{a}}$ \\
\hline Bacterial feeders $\%$ & 34.15 & $\pm 11.97^{\mathrm{a}}$ & 47.58 & $\pm 16.60^{\mathrm{a}}$ & 71.41 & $\pm 13.7^{b}$ & 64.84 & $\pm 16.05^{b}$ \\
\hline Fungal feeders \% & 17.92 & $\pm 11.49^{\mathrm{a}}$ & 9.59 & $\pm 4.93^{b c}$ & 4.10 & $\pm 2.01^{\mathrm{c}}$ & 13.35 & $\pm 4.12^{\mathrm{ab}}$ \\
\hline Plant parasites $\%$ & 9.29 & $\pm 10.76^{\mathrm{ab}}$ & 12.90 & $\pm 16.78^{b}$ & 1.46 & $\pm 1.31^{\mathrm{a}}$ & 3.26 & $\pm 3.05^{\mathrm{ab}}$ \\
\hline Root-fungal feeders $\%$ & 18.90 & $\pm 16.52^{\mathrm{a}}$ & 4.72 & $\pm 3.32^{c}$ & 8.19 & $\pm 6.91^{\mathrm{bc}}$ & 5.71 & $\pm 3.60^{\mathrm{c}}$ \\
\hline Omnivores $\%$ & 17.06 & $\pm 6.72^{\mathrm{ab}}$ & 21.70 & $\pm 11.69^{b}$ & 12.42 & $\pm 7.59^{\mathrm{a}}$ & 11.05 & $\pm 8.93^{\mathrm{a}}$ \\
\hline Predators \% & 1.81 & $\pm 2.01^{\mathrm{a}}$ & 0.38 & $\pm 0.60^{\mathrm{bc}}$ & 0.10 & $\pm 0.20^{\mathrm{c}}$ & 0.16 & $\pm 0.38^{c}$ \\
\hline Insect parasites \% & 4.01 & $\pm 5.60^{\mathrm{a}}$ & 3.14 & $\pm 4.33^{\mathrm{a}}$ & 2.32 & $\pm 5.92^{\mathrm{a}}$ & 1.63 & $\pm 2.16^{\mathrm{a}}$ \\
\hline MI & 3.03 & $\pm 0.46^{\mathrm{a}}$ & 2.98 & $\pm 0.32^{\mathrm{a}}$ & 2.58 & $\pm 0.31^{\mathrm{b}}$ & 2.52 & $\pm 0.40^{\mathrm{b}}$ \\
\hline PPI & 2.41 & $\pm 0.40^{\mathrm{a}}$ & 2.22 & $\pm 0.26^{\mathrm{a}}$ & 2.42 & $\pm 0.42^{\mathrm{a}}$ & 2.26 & $\pm 0.27^{\mathrm{a}}$ \\
\hline $\mathrm{PPI} / \mathrm{MI}$ & 0.81 & $\pm 0.20^{\mathrm{ab}}$ & 0.75 & $\pm 0.11^{\mathrm{a}}$ & 0.96 & $\pm 0.23^{b}$ & 0.91 & $\pm 0.16^{\mathrm{ab}}$ \\
\hline $\mathrm{B} / \mathrm{F}$ & 3.99 & $\pm 3.89^{\mathrm{a}}$ & 7.30 & $\pm 6.31^{\mathrm{ab}}$ & 21.35 & $\pm 9.77^{\mathrm{c}}$ & 5.73 & $\pm 2.88^{\mathrm{a}}$ \\
\hline EI & 41.73 & $\pm 19.20^{\mathrm{a}}$ & 31.73 & $\pm 18.51^{b}$ & 12.79 & $\pm 18.56^{\mathrm{c}}$ & 22.48 & $\pm 9.99^{\mathrm{bc}}$ \\
\hline SI & 77.98 & $\pm 12.77^{\mathrm{a}}$ & 73.92 & $\pm 9.86^{\mathrm{a}}$ & 52.26 & $\pm 19.85^{b}$ & 50.15 & $\pm 25.63^{b}$ \\
\hline
\end{tabular}

feeders prevailed, with statistical differences compared to those at the REF, EXT and NEX plots.

Using the Structure Index (SI) and Enriched Index (EI), many samples from the NEX scored in Quadrat D with a high $\mathrm{C}: \mathrm{N}$ ratio, stressed with degraded food web condition. On the other hand, a bulk of the soil samples from the REF, EXT and the FIR fell into Quadrat C - undisturbed with a moderate or higher $\mathrm{C}: \mathrm{N}$ ratio and structured food web condition.

\section{Discussion}

The analysis of the soil nematode communities from the damaged forest stands in the High Tatras indicates that the nematode species may be rather sensitive to forest ecosystems disturbance. The results indicated great differences in species distribution, abundance, trophic groups and some ecological indexes. A total number of 55 nematode species was found. That is relatively low in comparison to 74 species found by Háněl (1996) in spruce forest of the Czech Republic or to 69 and 93 species reported by Popovici (1980) from two mountain spruce forests in the Romania. However, Š́ly et al. (1986) reported 48 species identified in spruce forest of the Slovak Republic. The great abundance of nematodes in the FIR and NEX localities was mostly due to Acrobeloides nanus, with a low c-p value, classified by Bongers (1990) as a colonizer or r-strategies. Háněl (2001) also referred to an increasing abundance of Acrobeloides and Aphelenchoides due to litter accumulation. Háněl (1996) reported that Filenchus, Acrobeloides and Eudorylaimus are usually predominating genera in the spruce forests of Central Europe. In our study, these genera were also present, but only at the reference plot. A rapid increase in abundance of Plectus longicaudatus and $P$. parietinus was observed in damaged research plots, especially in the FIR locality. Sohlenius (1997) obtained simi- lar results in a clear-cut forest. On the other hand, the species Tylencholaimus mirabilis, Malenchus exiguus, Aglenchus agricola and Tylenchorhynchus sp. were less abundant in destroyed plots (EXT, FIR and NEX). That is in contrast to results of Clausi and Vinciguerra (1999) who reported a higher increase of $T$. mirabilis in clear cut forests than in maturing forests. Sohlenius and Wasilewska (1984) noted that the presence or absence of genus Tylencholaimus was determined by the composition of mycoflora communities, which can be influenced by nutrient status of soil.

In our study, bacterial feeders were the dominant trophic group in all research plots and were mainly represented by the genera Acrobeloides and Plectus. Rues \& Funke (1995) also found a greater proportion of bacterial feeders in the spruce forest soil in the Ore Mountains than fungal feeders. On the other hand, Háněl (1996) referred to the most abundant root-fungal feeders in spruce forest at the Boubín Mount. Bacterial-feeding nematodes were the most abundant in the FIR. As reported by Gömöryová et al. (2008) a thick humus layer in this plot was completely burnt down so that the mineral nutrients were released in to the mineral A-horizon. Water and temperature regimes have changed as well; a soil directly subjected to a solar radiation and at least a temporary increase in moisture were beneficial for the soil micro-organisms. Wasilewska (1997) reported an increased abundance of bacterial feeders related to an increase in readily decomposable organic matter of plant origin (e.g. burnt grass, litter, compost) and with an expansion of microbial activity with supplies of nitrogen in the environment.

The $\mathrm{B} / \mathrm{F}$ ratio provides information on the dominant way in which the breakdown of organic matter proceeds with the participation of bacteria or fungi and $\mathrm{B} / \mathrm{F}$ ratio increased in higher decomposition of organic matter (Wasilewska, 1997). In our study, the $B / F$ mean value was higher in the 
FIR in comparison to the REF, EXT, or NEX localities. Sohlenius (2002) reported increasing occurrence of bacteria and also abundance of bacterial feeder in disturbed forest during the period without trees and a higher occurrence of fungi and fungal feeders nematode during the forest development.

At the research plots, the MI and SI values were higher in the REF and EXT forest stands in comparison to the FIR and NEX localities. These results suggest that extracted forest has a stable and structured nematode assemblages and it is more similar to climax condition in the REF. On the contrary, no significant differences were found in the PPI values in our study.

When the number of species of plant parasitic nematodes in four plots is considered, only three species were found in the NEX locality, with a high abundance of Paratylenchus microdorus only, while in the REF seven species were found with a balanced number of individuals in several soil samples. In the REF locality, we found exclusively Criconemoides morgensis, Paratylenchus projectus, Tylenchorhynchus sp.

The PPI/MI mean values were lower in the REF and EXT localities, thus indicating natural habitats, where higher plants make optimal use of nutrient resources (Bongers et al., 1997).

In conclusion, variable results for composition and structure of nematode communities reflect both the disturbance of forest soil and a method of control after windfall and wildfire.

For a more comprehensive evaluation of changes in nematode communities, follow-up monitoring will be carried out in windfall-damaged forests of the High Tatras in the next periods.

\section{Acknowledgements}

This study was supported by the VEGA project No. 2/7191/27

\section{References}

Armendáriz, I., Hernández, M. A., Jordana, R. (1996): Temporal evolution of soil nematode communities in Pinus nigra forests of Navarra, Spain. Fundam. Appl. Nematol., 19: $561-577$

BAERMANN, G. (1917): Eine einfache Methode zur Auffindung von Ankylostomum (Nematoden) Larven in Erdproben. Geneesk. Tijdschr. Ned.-Indië 57: 131 - 137

BJøRnlund, L., VestergårD, M., JOHANSSON, S., NyborG, M., Steffensen, L., Christensen, S. (2002): Nematode communities of natural and managed beech forest - a pilot survey. Pedobiologia, 46: $53-62$

Bloemers, G. F., Hodda, M., LAmbshead, P. J. D., LAWTON, J. H., WANLESS, F. R. (1997): The effects of forest disturbance on diversity of tropical soil nematodes. Oecologia, 111: $575-582$

BONGERS, T. (1990): The maturity index: an ecological measure of environmental disturbance based on nematode species composition. Oecologia, 83: $14-19$
Bongers, T., Korthals, G. (1995): The behaviour of MI and PPI under enriched conditions. Nematologica, 41: 286 Bongers, T., VAN DER MEulen, H., Korthals, G. (1997): Inverse relationship between the nematode maturity index and plant parasite index under enriched nutrient conditions. Appl. Soil Ecol., 6: 195 - 199

Clausi, M., Vincigeuerra, M. T. (1999): Changes in nematode communities of forest soil in relation to clearcutting. Nematol. medit. 27: $315-322$

De Goede, R. G. M., Bongers, T., EtTema, C. H. (1993): Graphical presentation and interpretation of nematode community structure: $c-p$ triangles. Mededelingen-Faculteit Landbouwwetenschappen Universiteit Gent. 58: 743 747

Fenster, M., Ferrick, C., SCOTT, M. (2004): Fall burning does not affected nematode density or carbon and nitrogen levels in Iowa oak forest soil. Tillers 5: $9-12$

Ferris, H., Bongers, T., De Goede, R. G. M. (2001): A framework for soil food web diagnostics: extension of the nematode faunal analysis concept. Appl. Soil Ecol., 18: 13 $-29$

FLEISCHER, P., KOREŇ, M. (2007): Windfall research in the Tatra Mts. - purpose, objectives and status. In: FLEISCHER, P., MATEJKA, F. (Eds) Research after the Windthrow in the Tatra National Park. October 25 - 26, 2007, Tatranská Lomnica. Geophysical Institute of Slovak Academy of Sciences, Bratislava (In Slovak)

GÖMÖRYOVÁ, E., STŘElcovÁ, K., ŠKVARENINA, J., BEBEJ, J., GÖMÖRY, D. (2008): The impact of windthrow and fire disturbances on selected soil properties in the Tatra National Park. Soil \& Water Res., 3: $74-80$

HÁNĚL, L. (1996): Comparison of soil nematode communities in three spruce forests at the Boubín Mount, Czech Republic. Biologia, Bratislava, 51: 485 - 493

HÁNĚL, L. (2001): Succesion of soil nematodes in pine forests on coal-mining sands near Cottbus, Germany. Appl. Soil Ecol., 16: 23 - 34

HÁNĚL, L. (2003): Comparison of soil nematode communities in three forest types on sand and clay coal-mining dumps in Germany and Czech Republic. Helminthologia, 40: $237-243$

HÁNĚL, L. (2004): Response of soil nematodes inhabiting spruce forests in the Šumava Mountains to disturbance by bark beetles and clear-cutting. Forest Ecol. Manag., 202: $209-225$

LIŠKOVÁ, M. (2008): New records of mononchid nematodes from forests in the Slovak Republic. Helminthologia, 45: $134-136$

LiŠKovÁ, M. ČEREVKovÁ, A. HÁNĚL, L. (2008): Nematode communities of forest ecosystems in association with various soil orders. Russ. J. Nematol., 16: $129-142$

PavaO-Zuckerman, M. A., Coleman, D. C. (2007): Urbanization alters the functional composition, but not taxonomic diversity, of the soil nematode communities. Appl. Soil Ecol., 35: 329 - 339

POPOVICI, I. (1980): Distribution and dynamics of soil nematodes in mixed and spruce fir forest ecosystems. Rev. Roum. Bio. Sér. Biol. Anim., 25: 171 - 179 
Romanenko, E. N., Geltzer, J. G., Romanenko, N. D. (1997): The effect of soil disturbance in a spruce forest on the abundance of nematode trophic groups. Russ. J. Nematol., 5: 97 - 101

RUESS, L., FUNKE, W. (1995): Nematode fauna of a spruce stand associated with forest decline. Acta Zool. Fennica., $196,348-351$

ŠÁLY, A. (1983): Free living nematodes in the SSR. VEDA, Published House SAV, Bratislava (In Slovak)

ŠÁly, A., KalúZ, S. GouTh, S., ŠusteK, Z., ŽuffovÁ, Z., ŽUFFA, H. (1986): Inventory research on the selected groups of soil fauna in the State Natural Reserve Skalna Alpa in the Protected Landscape Area Vel'ká Fatra. Final report. ÚEBE CBEV SAV-OBP, Bratislava, 63 p.

Shannon, C. E. \& WeAVER, W. (1949): The Mathematical Theory of Communication. Urbana, University of Illinois Press

ŠimonoviČOVÁ, A., HanAJíK, P., LANCUCH, P., MiČUdA, R., HoŠKo, M., Dlapa, P., Ferians, P., Haydenová, J. (2007): Pedochemical characteristics, soil microorganismus and changes of plant community in the High Tatras Mts. after windthrow (2005 - 2006). FlEISCHER, P., MATEJKA, F. (Eds) Research after the Windthrow in the Tatra National Park. October 25 - 26, 2007, Tatranská Lomnica. Geophysical Institute of Slovak Academy of Sciences, Bratislava (in Slovak)
SoHlEnIUS, B. (1996): Structure and composition of the nematode fauna in pine forest soil under the influence of clear-cutting - Effects of slash removal and field layer vegetation. Eur. J. Soil Biol., 32: 1 - 14

SoHLENIUS, B. (1997): Fluctuation of nematode populations in pine forest soil. Influence by clear-cutting. Fundam. Appl. Nematol., 20: 103 - 114

SoHLENIUS, B. (2002): Influence of clear-cutting and forest age on the nematode fauna in a Swedish pine forest soil. Appl. Soil Ecol., 19: $261-277$

SoHlenius, B., Boström S. (2001): Annual and long term fluctuation of the nematode fauna in a Swedish Scots pine forest. Pedobiologia, 45: 408 - 429

SoHleniUs, B., WASILEWSKA, L. (1984): Influence of irrigation and fertilization on the nematode community in a Swedish pine forest soil. J. Appl. Ecol., 21: 327 - 342

STATSOFT, INC. 2001. STATISTICA Cz - Software system for data analysis, Release 6, www.statsoft.cz WASILEWSKA, L. (1997): Soil invertebrates as bioindicators, with special reference to soil-inhabiting nematodes. Russ. J. Nematol., 5: $113-126$

Yeates, G. W., Bongers, T., De Goede, R. G. M., Freckman, D. W., Georgieva, S. S. (1993): Feeding habits in nematode families and genera - an outline for soil ecologists. J. Nematol., 25: $315-331$ 